\title{
Distribution and factors associated with Fasciola hepatica infection in cattle in the south of Espírito Santo State, Brazil
}

Alves DP (1), Carneiro MB (1), Martins IVF (2), Bernardo CC (1), Donatele DM (2), Pereira Júnior OS (2), Almeida BR (1), Avelar BR (3), Leão AGC (3)

(1) Masters Program in Veterinary Science, Federal University of Espírito Santo, UFES, Alegre, Espírito Santo State, Brazil; (2) Federal University of Espírito Santo, UFES, Alegre, Espírito Santo State, Brazil; (3) Undergaduate Student, Veterinary Medicine, Federal University of Espírito Santo, UFES, Alegre, Espírito Santo State, Brazil.

\begin{abstract}
Fasciolosis is a disease that affects the liver parenchyma and bile ducts of numerous animals, including humans, which causes economic losses and threatens public health. The present work aimed at reporting the distribution and factors connected with Fasciola hepatica infection in cattle in ten municipalities in southern Espírito Santo, Brazil, between 2008 and 2009. During this period, 50 rural properties in ten cities were analyzed and fecal samples from $10 \%$ of the cattle on each farm were collected. Of the 717 samples analyzed, 154 (21.33\%) presented Fasciola hepatica eggs. As for the 50 rural properties studied, 32 (64\%) had animals positive for fasciolosis. Throughout the evaluation, it was observed that 42 $(84 \%)$ rural properties had flooded areas, 33 (66\%) were located at altitudes less than 226 meters, in 36 (72\%) mollusks were found, 47 (94\%) had other definitive hosts (horses, sheep, goats) and 25 (50\%) had previous cases of bovine fasciolosis. The present results showed a high rate of bovine fasciolosis in the analyzed region whereas infected animals are present in all the municipalities. Based on statistical analysis, it was concluded that there was an association between the presence of flooded areas and other definitive hosts in rural properties where bovine fasciolosis was detected.
\end{abstract}

Key words: fasciolosis, epidemiology, ruminants

\section{INTRODUCTION}

Fasciola hepatica is one of the most important helminths that parasitize domestic and wild animals in Brazil due to high mortality and morbidity rates of affected animals. Fasciolosis, the disease provoked by $F$. hepatica, comprises a relevant zoonosis in animal production, mainly in bovines and ovines, and also affects public health (1).

The development of fasciolosis involves the presence of an intermediate host (Lymnaea sp.), suitable habitats for mollusks and environmental factors such as high humidity, adequate temperature and rainfall. Furthermore, when infecting the definitive host, mature flukes lay eggs that spread in the environment and cause pasture recontamination (2).
According to Serra-Freire (3), cases of chronic disease were reported in all southern and southeastern states of Brazil except for Espírito Santo. However, at present, fasciolosis has become a severe economic issue for producers of the south region, particularly to those from Espírito Santo, regarding the possible contamination of bovine, ovine, caprine and bubaline flocks, the transportation of infected animals and the presence of the intermediate host in the hydrographic basins (4).

The present paper, therefore, aimed at reporting the distribution and factors related to Fasciola hepatica infection in cattle in ten municipalities in the south of Espírito Santo state between 2008 and 2009. 


\section{MATERIAL AND METHODS}

The database of the Forest and Agricultural Defense Institute (IDAF) was analyzed in the survey of municipalities and cattle farms in the south region of Espírito Santo state(ES). The region is composed of 22 cities of which ten were selected according to the following criteria: slaughtering registration at Atílio Vivácqua slaughterhouse (responsible for the slaughtering in the region), shared boundaries, different types of topography (from plain areas and lowlands to highlands), and proximity to the states of Rio de Janeiro and Minas Gerais. The analyzed municipalities were Muqui, Mimoso do Sul, Cachoeiro de Itapemirim, Atílio Vivácqua, Castelo, Alegre, Jerônimo Monteiro, Guaçuí, Presidente Kennedy and Muniz Freire all located between $20^{\circ} 23^{\prime}$ and $21^{\circ} 06^{\prime} \mathrm{S}$ latitude and $41^{\circ} 00^{\prime}$ and $41^{\circ} 84^{\prime} \mathrm{W}$ longitude.

During 2008 and 2009, 50 farms - five per each studied town - were strategically selected. The producers were contacted to arrange the visits, interviews and collection of biological samples. In each rural property, the manager was interviewed so as to inform cases of fasciolosis, environmental and utilization features of each studied area. The interviews were based on variables that are considered risk factors for $F$. hepatica infection, for example, flooded areas, the presence of other definitive hosts besides cattle (sheep, goats or horses), previous cases of fasciolosis, and the presence of mollusks in wetlands.

Subsequently, analyses were carried out in order to correlate positive and negative results of $F$. hepatica infection in farms with variables reported by the interviewees. The altitude of the properties was also taken into account, so that farms at $226 \mathrm{~m}$ were chosen.

Fecal samples were individually collected directly from the rectum of $10 \%$ of the animals (over 12 month-old), independently of gender and breed, identified and then placed in a box containing ice packs. Afterwards, the samples were sent to the Parasitology Laboratory of the Agricultural Science Center (CCA) of Federal University of Espírito Santo (UFES), so that they could be analyzed through sedimentation technique in the coproparasitologic diagnostic, described by Foreyt (5) and validated by Martins et al. (6), to detect F. hepatica eggs.

Distribution and frequency of Fasciola hepatica was calculated based on the results of fecal analyses. To identify geographic coordinates, altitude and the distribution of bovine fasciolosis in the region, GPS was employed to mark out the area. The marked areas were transferred to a map and put into GPS Trackmaker (Geo Studio Tecnologia Ltda, Brazil) program.

Associations of variables were assessed through chi-square test $\left(\chi^{2}\right)$ and, when necessary, Yates' correction and Fisher's exact test were applied together with EPI Info ${ }^{\star} 2002$ program (CDC, USA), $\mathrm{p} \leq 0.05$ was considered significant (7).

\section{RESULTS AND DISCUSSION}

Considering the ten municipalities studied in the southern region of Espírito Santo, of the 717 fecal samples collected, 153 tested positive, resulting in a frequency of $21.33 \%$ of fasciolosis. Of the 50 farms studied, 32 (64\%) were infected with $F$. hepatica and 18 (36\%) were not infected. Table 1 presents the frequency of bovine infection and the rural properties in each municipality where the parasite was found.

The present study is the first report of bovine fasciolosis in these municipalities in Espírito Santo. The studied area presents great epidemiologic importance due to its geographical position and the presence of two significant hydrographic basins. The Itabapoana River which flows through the states of Espírito Santo, Minas Gerais and Rio de Janeiro - and Itapemirim River - which runs through Minas Gerais and the south region of Espírito Santo - belong to these basins, allowing the disease to spread not only in Espírito Santo but also in other states.

The disease distribution map indicates that all the ten municipalities have cases of $F$. hepatica infection, with at least one positive rural property. Thus, it is correct to say that fasciolosis is spreading along the studied area (Figure 1).

The occurrence rate of Fasciola hepatica in some municipalities including Muqui, Jerônimo Monteiro, Cachoeiro de Itapemirim and Atílio Vivácqua was higher than in others. This may be explained by the presence of more lowland areas, which favors the emerging and maintenance of flood prone areas. Lima et al. (8) stated that these areas are suitable for mollusk dispersion and the maintenance of the life cycle of Fasciola hepatica. Moreover, the same authors observed an increase in F. hepatica natural infection in 13 municipalities, 
Table 1. Number of affected bovines and rural properties where Fasciola hepatica was found by coproparasitologic test in southern Espírito Santo state

\begin{tabular}{c|c|c}
\hline Municipality & Number of bovines (\%) & Number of rural properties (\%) \\
\hline Muqui & $56(41.07)$ & $5(100)$ \\
\hline Mimoso do Sul & $50(12.00)$ & $2(40)$ \\
\hline Cachoeiro de Itapemirim & $63(36.50)$ & $4(80)$ \\
\hline Atílio Vivácqua & $113(30.97)$ & $4(80)$ \\
\hline Castelo & $64(25.00)$ & $3(60)$ \\
\hline Alegre & $109(7.33)$ & $3(60)$ \\
\hline Jerônimo Monteiro & $63(39.68)$ & $4(80)$ \\
\hline Guaçuí & $31(9.67)$ & $3(60)$ \\
\hline Presidente Kenedy & $48(27.08)$ & $3(60)$ \\
\hline Muniz Freire & $120(7.50)$ & $1(20)$ \\
\hline Total & $717(21.33)$ & $32(64)$ \\
\hline
\end{tabular}

especially in Itajubá, Piranguinho and Cachoeira de Minas, with respective prevalences of 70 , 40 and $40 \%$. In the current study, all the rural properties had flood prone areas, thus favoring mollusk proliferation. As previously mentioned, all the analyzed municipalities had infected bovines. Moreover, municipalities with higher occurrence rate (concerning rural properties and bovines) bordered cities that are closer to the states of Rio de Janeiro and Minas Gerais, which characterizes the epidemiologic importance of fasciolosis in this region since the disease can spread through water.

Regarding Itajubá, in Minas Gerais state, several authors reported different bovine fasciolosis occurrence rates: $4 \%$ (9), a range from 9 to $13 \%$ (10) and $37.47 \%$ (11). The higher rate reported by Oliveira (11) may be the result of several factors: chronicity of $F$. hepatica infection in cattle plus the non-adoption of control measures (new infections were found); animal trade and significant increase in the number of bovines in the region (about 40\%), which is in accordance with the results presented in this study.

In the present study, the occurrence rate of Fasciola hepatica was $21.33 \%$ in the analyzed municipalities, being $41.7 \%$ in Muqui, $39.68 \%$ in Jerônimo Monteiro, 36.50\% in Cachoeiro de Itapemirim and $30.97 \%$ in Atílio Vivácqua. These higher rates are similar to those found by Oliveira (11) in the region of Minas Gerais. Besides, the same author observed that those rates increased over the years.

In the present work, the high rates may be closely related to the presence of chronic bovine infection due to non-adoption of control measures, indiscriminate animal trade and transport with no parasite control, favorable environmental conditions for intermediate host maintenance and gradual increase of cattle in the region (11).

When variables were assessed, 42 (84\%) rural properties had flooded areas, $33(66 \%)$ were at 226 maltitude (or less), 36 (72\%) reported the presence of mollusks, 47 (94\%) had other definitive hosts (horses, sheep or goats) and 25 (50\%) reported previous cases of bovine fasciolosis.

Numerous positive rural properties had wetlands, which shows an association among variables $(p \leq 0.05)$, since they favor the survival of the intermediate host (a risk factor for fasciolosis spread). The south of the Espírito 


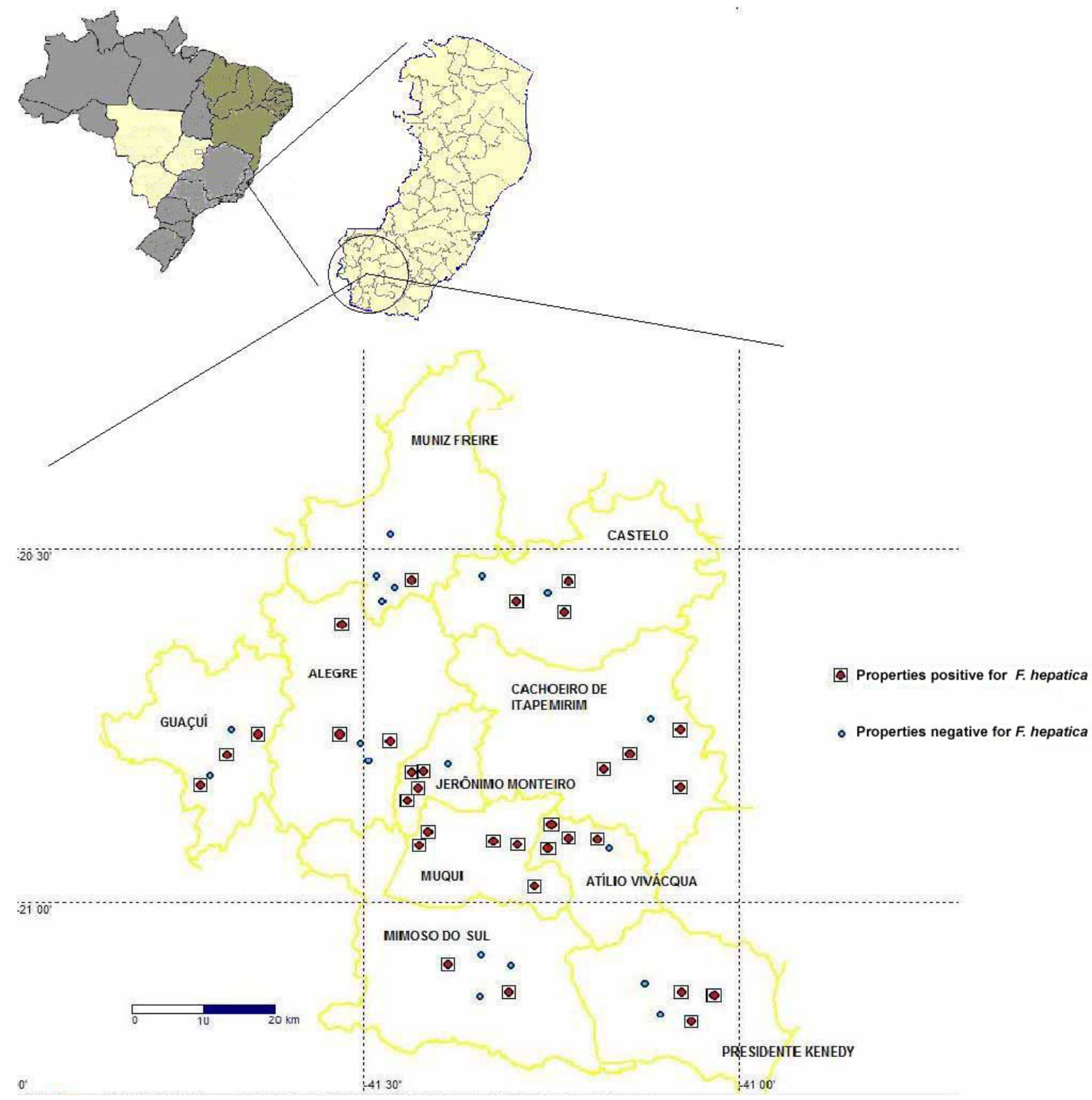

Figure 1. Schematic representation of the rural properties in ten cities of the south of Espírito Santo state, Brazil.

Santo is characterized by prolonged droughts and heavy summer rains, which in association with the tropical climate favor mollusk development and consequently the parasite cycle and disease spread.

In a study carried out in the cities of Itajubá and Careaçu, Minas Gerais state, Oliveira (11) found that $89 \%$ of the positive cases of bovine fasciolosis were closely related to flooded areas. Moreover, in Curitiba, Paraná state, Busetti (12) reported that Lymnaeidae mollusks were found in flood plain areas in watercress crops, thus creating a human contamination focus. The present study corroborates previous works that indicate a strong connection between flood plain areas and fasciolosis.

Regarding altitude (average altitude of the studied rural properties was $226 \mathrm{~m}$ ), there is no association with the number of positive rural properties $(p>0.05)$. Although the variable altitude had no association with positive results for F. hepatica, it is known that low altitude may influence fasciolosis occurrence in southern Espírito Santo since most rural properties are in plain areas, which favors the development of intermediate hosts. This is in agreement with the reports of Lemma et al. (13), who stated that different altitudes influence $F$. hepatica occurrence 
rate in plain pastures. Oliveira (11) also observed that most cattle positive for $F$. hepatica were found in rural properties located in plain areas. However, positive areas presented altitude equal to or lower than the average altitude of the rural properties herein evaluated.

In the current work, no mollusks were collected in the analyzed rural properties. Nevertheless, during the same period, Lymnaea columella mollusks were found in all the municipalities in a study conducted in parallel. The present results showed that there was no association between positive rural properties and presence of mollusks ( $p>0.05$ ). This finding can be explained not only by the lack of knowledge on Lymnaea mollusks by the interviewees, but also by the great difficulty on finding this mollusk since it usually remains adhered to vegetation or buried in mud.

There is a relation between the number of positive rural properties and definitive hosts (horses, sheep or goats) $(\mathrm{p}<0.05)$. In a study on fasciolosis in ruminants carried out in Mexico, the prevalence in bovines was $11.44 \%$, in goats was $24.55 \%$ and in ovines was $19.4 \%$ (14). In the present work, considering the analyzed regions, the percentages of other ruminants positive for $F$. hepatica was: $13.68 \%$ for sheep, $21.78 \%$ for goats and $23.81 \%$ for buffaloes, which indicates a high occurrence of the disease among these animals in the south of Espírito Santo (unpublished data). These results suggest that sheep and goats are $F$. hepatica main hosts, which favors a wide dissemination of eggs in the environment and, consequently, a higher risk of infection for cattle, as observed in the present work through the relation between other definitive hosts and rural properties positive for fasciolosis.

Based on the interviews, it was observed that $25(50 \%)$ of the rural properties had previous cases of bovine fasciolosis. No association was found ( $p>0.05)$ between positive rural properties and previous cases of the disease. However, an epidemiological correlation between the report of fasciolosis cases and the number of new cases was observed. The non-adoption of control measures is confirmed by the augment in the number of cases in the state of Espírito Santos. Fasciolosis occurrence may increase or decrease depending on changes of several factors that influence the parasite life cycle such as climate, environment and control measures. Nonetheless, it is still difficult to prevent the disease.
Moreover, the relation between flooded areas and F. hepatica, together with the lack of association between F. hepatica and the observation of mollusks by owners, indicates the difficulty of interviewees in recognizing the intermediate host.

\section{CONCLUSIONS}

The average rate of bovine fasciolosis was high in the analyzed region, which shows that there are infected bovines in all the municipalities. The variables flooded areas and presence of other hosts in rural properties were characterized as factors of epidemiologic risks for Fasciola hepatica in bovines in ten municipalities in the south of Espírito Santo, which reveals the disease dissemination in this state and other regions.

\section{ACKNOWLEDGEMENTS}

We are thankful to The State of Espírito Santo Research Foundation (FAPES) and the Coordination for the Improvement of Higher Education Personnel (CAPES) for the financial support.

\section{COPYRIGHT \\ (C) CEVAP 2011}

\section{SUBMISSION STATUS}

Received: November 11, 2010.

Accepted: April 12, 2011.

Abstract published online: April 18, 2011.

Full paper published online: August 31, 2011.

\section{CONFLICTS OF INTEREST}

There is no conflict.

\section{FINANCIAL SOURCE}

FAPES and CAPES provided the financial grants.

\section{CORRESPONDENCE TO}

ISABELLA VILHENA FREIRE MARTINS, Departamento de Medicina Veterinária, Alto Universitário, s/n, caixa postal 16, Alegre, ES, 29500-000, Brazil. Phone: +55 2835528643. Email: ivfmartins@yahoo.com.br.

\section{REFERENCES}

1. Echevarria FA, Correa MB, Wehrle RD, Correa IF. Experiments on anthelmintic control of Fasciola hepatica in Brazil. Vet Parasitol. 1992;43(3-4): 211-22. 
2. Costa NC, Silva Santos IC, Botelho GA. Myocastor coypus MOLINA, 1782 (Rodentia, Echymidae) naturalmente infectado com fasciola hepática (Linnaeus, 1758) (Trematoda, Fasciolidae). Hora Vet. 1987;6(36):24-6.

3. Serra-Freire NM. Fasciolose hepática. Hora Vet. 1995;1(1):13-18.

4. Fraga JCL. Incidência de fasciolose hepática bovina no sul do Espírito Santo [dissertation]. Vitória: Universidade Castelo Branco; 2008. 29 p. Available from: http://www.qualittas.com.br/documentos/ Incidencia $\% 20 \mathrm{da} \% 20 \mathrm{Fasciolose} \% 20 \mathrm{Hepatica} \% 20$ Bovina\%20no\%20Sul\%20-\%20Jose\%20Carlos\%20 Landeiro\%20Fraga.PDF

5. Foreyt WJ. Parasitologia veterinária: manual de referência. 5th ed. São Paulo: Roca; 2005.

6. Martins IVF, Bernardo CC, Avelar BR, Araújo IBBA, Donatele DM, Nunes LC. Sensibilidade e reprodutibilidade da técnica de sedimentação (Foreyt, 2005) para o diagnóstico de Fasciola hepatica. Rev Bras Parasitol Vet. 2008; 17(Suppl 1):110-2.

7. Center for Disease Control and Prevention (CDC) 2002. Epi Info. [updated 2008 Oct 1]. Available from: http://www.cdc.gov/epiinfo/ei2002.htm.

8. Lima WS, Soares LR, Barçante TA, Magalhães MP, Barçante JM. Ocurrence of Fasciola hepatica (Linnaeus, 1758) infection in Brazilian cattle of Minas Gerais, Brazil. Rev Bras Parasitol Vet. 2009;18(2):2730.
9. Serra-Freire NM, Bordin EL, Lessa CSS, Scherer PO, Farias MT, Malacco MA, et al. Reinvestigação sobre a distribuição da Fasciola hepatica no Brasil. Hora Vet. 1995;15(1):19-21.

10. Faria RN, Cury MC, Lima WS. Prevalence and dynamics of natural infection with Fasciola hepatica (Linnaeus, 1758) in Brazilian cattles. Rev Med Vet. 2005;156(2):85-6.

11. Oliveira EL. Prevalência e fatores associados à distribuição da Fasciola hepatica (Linnaeus, 1758) em bovinos dos municípios de Careaçú e Itajubá, região da bacia do rio Sapucaí, Minas Gerais [dissertation]. Belo Horizonte: Universidade Federal de Minas Gerais; 2008. Available from: http://www.dominiopublico. gov.br/download/texto/cp098918.pdf

12. Busetti ET. Informações adicionais sobre a fasciolose hepática em Curitiba (Estado do Paraná, Brasil). Rev Inst Med Trop São Paulo. 1982;24(2):104-6.

13. Lemma B, Gabre-ab F, Tedla S. Studies on fascioliasis in four selected sites in Ethiopia. Vet Parasitol. 1985;18(1):29-37.

14. Munguía-Xóchihua JA, Ibarra-Velarde F, DucoingWatty A, Montenegro-Cristino N, Quiroz-Romero H. Prevalence of Fasciola hepatica (ELISA and fecal analysis) in ruminants from a semi-desert area in the Northwest of Mexico. Parasitol Res. 2007;101(1):12730 . 